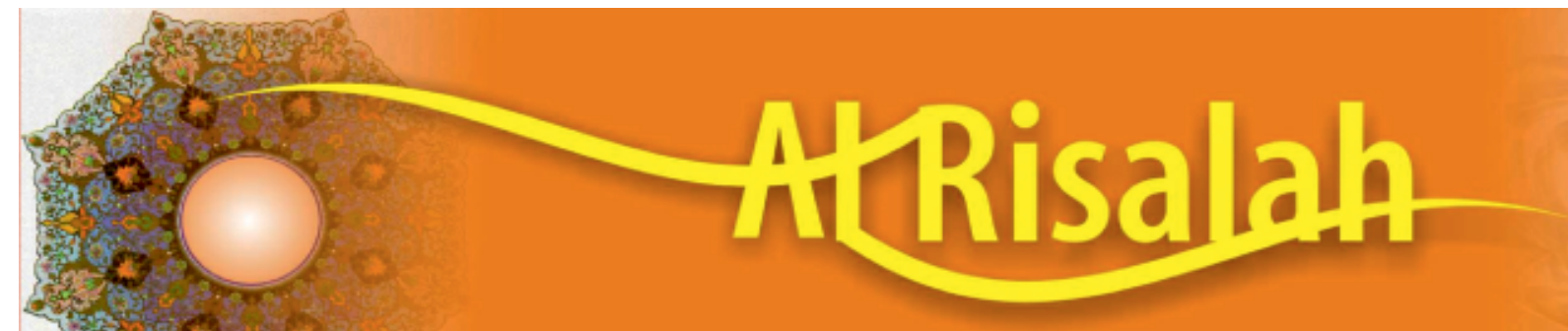

FENOMENA PEMAHAMAN DAN PENERAPAN HAKIKAT MAKNA KATA KEJAHATAN DAN PELANGGARAN DALAM PERKEMBANGAN HUKUM

Hamsir

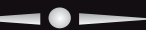

IJTIHAD DAN URGENSINYA

Usman Jafar

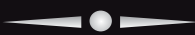

PARTISIPASI POLITIK DALAM KONSEPSI TEORI PILIHAN RASIONAL JAMES S COLEMAN

Nila Sastrawati

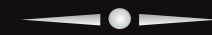

THAHARAH LAHIR DAN BATIN DALAM AL-QURAN

(Penafsiran terhadap Qs. Al-Muddatsir/74:4 dan Qs. Al-Maidah/5:6)

Ahmad Mujahid, Haeriyyah

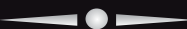

STUDI KRITIS PERNIKAHAN BAWAH UMUR PERSPEKTIF UUP NO. 16 TAHUN 2019 DAN GENDER ANALISIS

Sippah Chotban

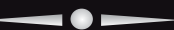

HISAB HAKIKI:

Metode IImiah Penentuan Awal Bulan Kamariyah

Alimuddin

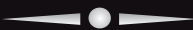

POLIGAMI DALAM SOROTAN

(Kajian Kitab-kitab Tafsir Modern/Kontemporer)

Halimah B

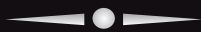

PERILAKU SEKSUAL TRANSGENDER (Studi Komparatif Hak Asasi Manusia Antara Perspektif

The Universal Declaration of Human Right dan The Cairo Declaration of Human Right)

Adriana Mustafa

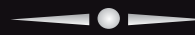

ADAT AMPIKALE:

Asuransi Ala Masyarakat Bugis di Kecamatan Pammana Kabupaten Wajo

Hadi Daeng Mapuna

\title{
MEDIA SOSIAL DAN DAMPAKNYA TERHADAP PERCERAIAN \\ Sohrah
}

זיז: HIMPUNAN ILMUWAN DAN SARJANA SYARIAH INDONESIA 


\section{$\underline{\text { Al-Risalah }}$}

Jurnal Ilmu Syariah dan Hukum

\section{DAFTAR ISI}

FENOMENA PEMAHAMAN DAN PENERAPAN HAKIKAT MAKNA KATA

KEJAHATAN DAN PELANGGARAN DALAM PERKEMBANGAN HUKUM

Hamsir

IJTIHAD DAN URGENSINYA

Usman Jafar

PARTISIPASI POLITIK DALAM KONSEPSI TEORI PILIHAN

RASIONAL JAMES S COLEMAN

Nila Sastrawati

THAHARAH LAHIR DAN BATIN DALAM AL-QURAN

(Penafsiran terhadap Qs. Al-Muddatsir/74:4 dan Qs. Al-Maidah/5:6)

Ahmad Mujahid, Haeriyyah

STUDI KRITIS PERNIKAHAN BAWAH UMUR PERSPEKTIF UUP NO. 16

TAHUN 2019 DAN GENDER ANALISIS

Sippah Chotban

HISAB HAKIKI: Metode Ilmiah Penentuan Awal Bulan Kamariyah

Alimuddin

POLIGAMI DALAM SOROTAN (Kajian Kitab-kitab Tafsir

Modern/Kontemporer)

Halimah B 
PERILAKU SEKSUAL TRANSGENDER

254-275

(Studi Komparatif Hak Asasi Manusia Antara Perspektif The Universal

Declaration of Human Right dan The Cairo Declaration of Human Right)

Adriana Mustafa

ADAT AMPIKALE: Asuransi Ala Masyarakat Bugis di Kecamatan Pammana

Kabupaten Wajo

276-285

Hadi Daeng Mapuna

MEDIA SOSIAL DAN DAMPAKNYA TERHADAP PERCERAIAN

286-296

Sohrah 


\section{PERILAKU SEKSUAL TRANSGENDER (Studi Komparatif Hak Asasi Manusia Antara Perspektif The Universal Declaration of Human Right dan The Cairo Declaration of Human Right)}

Adriana Mustafa

Fakultas Syariah dan Hukum UIN Alauddin Makassar

\section{Abstract}

The emergence of the term Transgender in Indonesia first appeared in 1860 and underwent development in the 1990s. In 1986 the term Wadam (Female Adam) emerged, but changed into a transsexual (Male Female). The amendment was based on the objection of several parties because of the use of the name of Adam's Woman. It was considered impolite because the name of the Prophet Adam as.

In the Universal Declaration of Human Right, there is indeed no mention of sexual orientation, it must be of the opposite sex, what is concerned about human rights to marry and build families, namely article 16 which is then used as a basis by transgender people to justify deviant sexual behavior they are through same-sex marriage. On the other hand, in the Universal Declaration of Human Right there is also article 18 which guarantees the right of everyone to believe in the teachings of his religion and practice his religious teachings well. While we all know there is no religious teaching in this world that allows sexual behavior to deviate, even the most tolerant religion.

Keywords: Transgender, Sexual Behavior, Human Rights, Religious Teachings

\section{A. PENDAHULUAN}

Setiap manusia lahir dengan membawa hak asasi yang melekat dan tidak dapat dihilangkan. Pada dasarnya hak asasi manusia berlaku universal tanpa dipengaruhi oleh ras, suku dan agama. Tapi pada praktiknya, di kehidupan nyata tidak semua orang memiliki kebebasan yang sama. Terlebih jika individu tersebut masuk ke dalam kelompok minoritas. Pemenuhan hak asasi dipengaruhi aspek seperti gender, kelas sosial dan berbagai prasangka lain yang terbentuk bergantung pada konstruksi (susunan) sosial. ${ }^{1}$

Kedudukan laki-laki dan perempuan sama kecuali dalam hal ketakwaan, sebagaimana firman Allah dalam QS Al-Hujurat/49:13. Pada dasarnya Tuhan menciptakan manusia terdiri dari dua jenis kelamin yaitu laki-laki dan perempuan, namun pada kenyataannya selain dari dua jenis kelamin tersebut ada yang mengalami kebingungan dalam menentukan jenis kelamin dan kejiwaannya. Keadaan inilah yang disebut transgender. Jadi, transgender adalah istilah yang digunakan untuk mendeskripsikan orang yang melakukan, merasa, berpikir atau terlihat berbeda dari jenis kelamin yang di tetapkan saat mereka

${ }^{1}$ Anindita Ayu Pradipta Yaudah dan Irak Sulhin, Representasi Transgender dan Transeksual dalam Pemberitaan di Media Massa. http://journal.ui.ac/index.php (Diakses 14 Oktober 2018). 
lahir. ${ }^{2}$ Ketidakpuasan tersebut kemudian diwujudkan dalam berbagai macam cara mulai dari merubah kebiasaan jalan, bicara, pakaian, memakai perhiasan dan dandanan sampai pada usaha melakukan operasi penggantian kelamin. ${ }^{3}$

Dengan perkembangan zaman yang semakin modern, permasalahan transgender tidak terbatas hanya pada peralihan secara fisik dan keinginan untuk melakukan pergantian jenis kelamin. Akan tetapi telah sampai pada keinginan untuk penaluran seks biologisnya. Namun fenomena transgender untuk selalu ingin melakukan penggantian kelamin tidak sepenuhnya selalu terjadi.

Setelah Amerika Serikat dan beberapa Negara Barat serta Asia melakukan pelegalan pernikahan sesama jenis, fenomena lesbian, gay, biseksual dan transgender mencuat ke permukaan dan merebut perhatian publik tidak terkecuali di Indonesia. Tidak sedikit dari masyarakat Indonesia yang menganggap bahwa kaum lesbian, gay, biseksual dan transgender sebagai kaum yang menyalahi kodrat manusia, kaum Nabi Luth, kaum perusak moral, hama masyarakat, sampah masyarakat, pengundang malapetaka, penyandang cacat mental dan sebagai penghancur norma-norma sosial dan agama. ${ }^{4}$

Meskipun masyarakat Indonesia memberikan stigma yang negatif terhadap kaum lesbian, gay, biseksual dan transgender, namun penyebaran dan perkembangannya tidak dapat dielakkan. Tercatat bahwa Indonesia menjadi negara ke lima dengan penduduk lesbian, gay, biseksual dan transgender terbanyak setelah Cina, India, Eropa dan Amerika. Beberapa lembaga survei independen dalam negeri dan luar negeri menyebutkan bahwa Negara Indonesia memiliki penduduk lesbian, gay, biseksual dan transgender sebanyak $3 \%$, yang artinya dua ratus juta penduduk Indonesia dari tujuh koma lima juta penduduk merupakan kaum lesbian, gay, biseksual dan transgender atau dengan kata lain tiga dari seratus orang yang berkumpul di suatu tempat merupakan lesbian, gay, biseksual dan transgender. ${ }^{5}$

Dalam merespon permasalahan lesbian, gay, biseksual dan transgender, terdapat tiga sikap masyarakat Indonesia yaitu pro, kontra dan tidak peduli dengan hal tersebut. Masyarakat yang pro terhadap lesbian, gay, biseksual dan transgender beralasan untuk menghargai setiap hak asasi manusia dan kebebasan untuk menyuarakan dan menentukan hidup. Masyarakat yang kontra beranggapan bahwa lesbian, gay, biseksual dan transgender merupakan

\footnotetext{
${ }^{2}$ Fitri Meliya Sari, "Konstruksi Media Terhadap Transgender", Jurnal profesional UNIVED, vol. 3 no. 1 (Juni 2016), h. 27. https://jurnal.unived.acid/index.php/prof/article/download/290/277/\&ved (Diakses 17 Februari 2019).

${ }^{3}$ Suhaimi Razak, "Lgbt Dalam Perspektif Agama", Madura al-Ibrah, vol. 1 no. 1 (Juni 2016), h. 54. Download.Garuda.Risetdikti.Go.Id (Diakses 14 oktober 2018).

${ }^{4}$ Muhammad Rizki Akbar Pratama, dkk., "Lesbian, Gay, Biseksual dan Transgender: Tinjauan Teori Psikoseksual, Psikologi Islam dan Biopsikologi”, Jurnal Psikologi Islami, vol. 4 no. 2 (Juni 2018), h. 28. http://jurnal.radenfatah.ac.id/index.php/psikis/article/download/2157 /1569/\&ved (Diakses 14 Oktober 2018).

${ }^{5}$ Meilanny Budiarti Santoso, "LGBT Dalam Perspektif Hak Asasi Manusia", Sosial Work Journal, vol. 6 no. 2 (2016), h. 221. http://jurnal.unpac.id.ac.id/share/article/download/ 13206/6036\&ved (Diakses 14 Oktober 2018).
} 
virus yang dapat merusak norma-norma sosial, agama dan memutus garis keturunan. Sedangkan masyarakat yang tidak peduli memilih biasa-biasa saja dan tidak peduli. ${ }^{6}$

\section{B. PEMBAHASAN}

\section{Fenomena Transgender dalam Masyarakat}

Fenomena lesbian, gay. biseksual dan transgender semakin menarik ketika pada bulan Oktober 2015, Sekretaris Jendral Perserikatan Bangsa-Bangsa, Ban Ki-Moon mengaku akan menggencarkan perjuangan persamaan hak-hak lesbian, gay, biseksual dan transgender. Bersamaan dengan itu, United States Agency For Internasional Development Program (UNDP) pun turut mendukung hak asasi kaum lesbian, gay, biseksual dan transgender yang menurutnya komunitas terrsebut sering mendapat diskiminasi, penganiayaan, hingga kekerasan di lingkungan masyarakat. Pernyataan Sekretaris Jendral Perserikatan Bangsa-Bangsa dan dukungan United States Agency For Internasional Development Program mencerminkan adanya sebuah keinginan untuk mendorong persamaan hak bagi kaum lesbian, gay, biseksual dan transgender dan diterima negara-negara di dunia. ${ }^{7}$

Hampir di semua negara di dunia tidak luput dari fenomena transgender. Upaya ini dilatarbelakangi kelompok-kelompok internasional yang bertujuan agar keberadaan mereka yang minoritas di suatu negara benar-benar terlindungi. ${ }^{8}$ Di Indonesia, kemunculan lesbian, gay, biseksual dan transgender sudah ada sejak lama dan jumlahnya terus meningkat. Dukungan Perserikatan Bangsa-Bangsa, Amerika Serikat dengan perangkat diplomasinya, serta dana dari United States Agency for Internasional Development Program membuat isu lesbian, gay, biseksual dan transgender menjadi kian rumit. Fenomena tersebut dapat dipandang sebagai hegemoni budaya Barat yang berupaya mengkampanyekan semangat emansipatoris yang tidak sesuai dengan nilai dan norma di Indonesia. Indonesia harus membendung hegemoni tersebut melalui kalangan intelektual organik untuk menciptakan katarsis supaya Indonesia mampu menjaga nilai dan norma yang dianutnya. ${ }^{9}$

Pada tanggal 19 April 1981 masyarakat Indonesia dikejutkan dengan pemberitaan perkawinan dua wanita lesbian yang digelar di daerah Blok M Jakarta Selatan dan dihadiri sekitar 120 undangan. Peristiwa ini menjadi

${ }^{6}$ Muhammad Rizki Akbar Pratama, dkk., "Lesbian, Gay, Biseksual Dan Transgender: Tinjauan Teori Psikoseksual, Psikologi Islam dan Biopsikologi”, Jurnal Psikologi Islami, vol. 4 no. 2 (Juni 2018), h. 29. http://jurnal.radenfatah.ac.id/index.php/psikis/article/download/2157 /1569/\&ved (14 Oktober 2018).

${ }^{7}$ Hartanto, Hegemoni Dalam Emansipatory: Studi Kasus Advokasi Legalisasi Lesbian, Gay, Biseksual, dan Transgender (LGBT) Di Indonesia. http://ejournal.undip.ac.id (Diakses 20 Februari 2019).

${ }^{8}$ Chorul Nur Akrom, “Transgender dalam Perspektif Hukum Positif dan Hukum Islam”. Skripsi (Palembang: Fakultas Syariah dan Hukum UIN Raden Fatah, 2017).

${ }^{9}$ Hartanto, Hegemoni Dalam Emansipatory: Studi Kasus Advokasi Legalisasi Lesbian, Gay, Biseksual, dan Transgender (LGBT) Di Indonesia. http://ejournal.undip.ac.id (Diakses 04 November 2018). 
pemberitaan menghebohkan di kalangan masyarakat, bahkan tidak sedikit yang mengutuknya. Anehnya, pengamat homoseksual Barat, Tom Boelstroff dalam bukunya the gay archipelago, sexuality and nation in Indonesia, justru memuji keberanian pasangan ini dan menobatkannya sebagai pejuang yang berani membela hak-hak lesbian yang harus diakui publik Indonesia. ${ }^{10}$

Pada tahun 2006 di Yogyakarta telah ditetapkan satu dokumen bernama prinsip-prinsip Yogyakarta (The Yogyakarta Principle), yang berisi tentang penerapan hukum hak asasi manusia internasional dalam kaitannya dengan orientasi seksual dan identitas gender. Prinsip-prinsip yang dikembangkan pada pertemuan komisi ahli hukum internasional, internasional service for human rights dan hak asasi manusia dari seluruh dunia di Universitas Gadjah Mada pada tanggal 6 sampai tanggal 9 November 2006.11

\section{Pengertian dan Sejarah the Universal Declaration of Human Right (UDHR) dan the Cairo Universal Declaration of Human Right (CDHR) \\ a. Pengertian dan Sejarah Perkembangan the Universal Declaration of Human Right (UDHR)}

Hak asasi manusia dalam bahasa Prancis di sebut dengan droit $l^{\prime}$ homme yang berarti hak-hak manusia, dalam bahasa Inggris disebut dengan human right. Sejalan dengan perkembangan zaman dan ajaran negara hukum, manusia diposisikan sebagai warga negara yang mempunyai hak-hak utama dan mendasar yang wajib dilindungi oleh negara. Berdasarkan dari hal tersebut, muncullah istilah basic rights atau fundamental right yang artinya hak asasi manusia. ${ }^{12}$

The Universal Declaration of Human Right terdiri atas tiga puluh pasal yang dimulai dari mukaddimah. Pasal 1 dan pasal 2 berisi pernyataan bahwa manusia mempunyai kedudukan hak yang didapat sejak lahir dan tanpa diskriminasi atas dasar apapun itu, baik warna kulit, suku, keturunan dan lain sebagainya. Pasal 3 sampai dengan pasal 21 berisi pernyataan tentang hak-hak individu, sedangkan dalam pasal 22 sampai pasal 27 berbicara mengenai hak ekonomi, sosial termasuk hak untuk mendapatkan pekerjaan yang layak, mendirikan serikat buruh, berorganisasi, anak-anak berhak untuk mendapatkan keamanan sosial dan pendidikan, hak untuk memilih agama dan berpindah agama serta menjalankan agama. Adapun pasal 28 sampai pasal 30 berisi tentang ketentuan-ketentuan tentang kebutuhan akan sebuah kerangka kerja agar semua hak dapat terealisasikan. ${ }^{13}$

The Universal Declaration of Human Right atau deklarasi universal hak asasi manusia merupakan instrumen payung bagi seluruh instrumen hak asasi manusia yang lain. Disebut sebagai instrumen payung karena seluruh

\footnotetext{
${ }^{10}$ Hendri Shalauddin, "Menyongsong Kebangkitan Kaum Nabi Luth Di Indonesia", http://Thisisgender.Com (Diakses 20 Februari 2019).

${ }^{11}$ Adian Husaini, LGBT di Indonesia: Perkembangan dan Solusinya (Jakarta: Insist, t.th ), h. 2.

${ }^{12}$ Meilanny Budiarti Santoso, "LGBT Dalam Perspektif Hak Asasi Manusia", Sosial Work Journal, vol. 6 no. 2 (2016), h. 222. http://jurnal.unpac.id.ac.id/share/ article/download/13206/6036\& ved (Diakses 26 Oktober 2018).

${ }^{13}$ Ihsan Ali Fauzi, Hak Asasi Manusia (Jakarta: PT. Ikhtiar Baru Van Hoeve, 2002), h. 161.
} 
instrumen hak asasi manusia, baik instrumen internasional, regional dan nasional. Keseluruhannya merujuk kepada deklarasi tersebut. The Universal Declaration of Human Right merupakan dokumen pengakuan internasional terhadap hak asasi manusia. Deklarasi ini diterima melalui Resolusi Majelis Perserikatan Bangsa-Bangsa pada tanggal 10 desember 1948. ${ }^{14}$ The Universal Declaration of Human Right terdiri atas tiga puluh pasal yang mengatur perlindungan hak-hak fundamental yang paling penting mengenai perlindungan terhadap hak-hak sipil dan politik serta hak-hak ekonomi, sosial dan budaya. ${ }^{15}$

Deklarasi ini menjadi dokumen hak asasi manusia paling pokok. Deklarasi ini tidak mengikat secara hukum, namun ia dianggap sebagai hukum kebiasaan internasional (customary internasional law).

The Universal Declaration of Human Right merupakan pengakuan terhadap hak-hak asasi manusia yang didalamnya menjabarkan bahwa hak-hak asasi manusia perlu dilindungi guna menciptakan kebebasan untuk berbicara, beragama dan bebas dari ketakutan. Deklarasi ini diadopsi oleh perserikatan bangsa-bangsa pada tanggal 10 November 1948 dengan hasil voting 48-0 termasuk di dalamnya Uni Soviet, Afrika Selatan dan Arab Saudi. Deklarasi ini terbagi atas dua bagian, yaitu economic and social right dan civil and political rights. Deklarasi ini dianggap memiliki nilai sebagai customary internasional law. Sekertaris Jenderal Perserikatan Bangsa-Bangsa pada tahun 1967 menyatakan bahwa deklarasi ini telah diadopsi ke dalam konstitusi tertulis di empat puluh tiga negara. ${ }^{16}$

Deklarasi ini mengandung beberapa prinsip-prinsip yaitu pertama, pengakuan terhadap martabat dasar dan hak-hak yang sama dan sejajar sebagai dasar dari kemerdekaan, keadilan dan perdamaian dunia. Kedua, membangun hubungan yang baik antarbangsa. Ketiga, perlindungan hak asasi manusia dengan rule of law. Keempat, persamaan antara laki-laki dan perempuan. Dan kelima, kerjasama antara negara dengan perserikaan bangsa-bangsa untuk mencapai pengakuan universal terhadap hak asasi manusia dan kebebasan dasar. ${ }^{17}$

\section{b. Pengertian dan sejarah perkembangan the Cairo Universal of Human Right (CDHR)}

Hak asasi manusia adalah seperangkat hak yang melekat pada hakekat dan keberadaan manusia sebagai makhluk Tuhan Yang Maha Esa dan merupakan anugerah-Nya yang wajib dihormati, dijunjung tinggi dan

\footnotetext{
${ }^{14}$ Naskah Lengkap the Universal Declaration of Human Right.

${ }^{15}$ Sunaryo, "Studi Komparatif Antara the Declaration of Human Right 1948 dan the Cairo Declaration of Human Right In Islam 1990", h. 390. http:/Jurnal.Fh.Unila.Ac.Id/Index.Php/Fiat/ Article/View/61/0\&Ved (Diakses 24 Maret 2018).

${ }^{16}$ Internasional Law Making, "Deklarasi Universal Hak-Hak Asasi Manusia", Jurnal Hukum Intenasional, vol. 4 no. 1 (Oktober 2006), h. 133-135. http://ijil.ui.ac.id/index.php/home/article/ download/468/pdf_354\&ved (Diakses 24 Maret 2018).

${ }^{17}$ Internasional Law Making, "Deklarasi Universal Hak-Hak Asasi Manusia", Jurnal Hukum Intenasional, vol. 4 no. 1 (Oktober 2006), h. 135. http://ijil.ui.ac.id/index.php/home/article/download 1468/pdf_354\&ved (Diakses 24 Maret 2018).
} 
dilindungi negara, hukum, pemerintah dan setiap orang, demi kehormatan serta perlindungan harkat dan martabat manusia. ${ }^{18}$

Pada tahun 1990 Organisasi Konferensi Islam mengeluarkan suatu deklarasi mengenai hak asasi manusia versi Islam yang dikenal dengan the Cairo Declaration of human right atau deklarasi kairo. Deklarasi tersebut dibuat sebagai acuan bagi negara anggota Organisasi Konferensi Islam dalam rangka pelaksanaan perlindungan terhadap hak asasi manusia yang berdasarkan Islam. The Cairo Declaration of human right terdiri atas 25 pasal yang mengatur tentang hak asasi manusia, baik dalam bidang politik juga hak ekonomi, sosial dan budaya. The Cairo Declaration of human right ingin memberikan sumbangan bagi usaha-usaha manusia dalam menegakkan hak asasi manusia yang sesuai dengan Syariat Islam. Selain itu, hak asasi manusia merupakan bagian integral dari Agama Islam yang merupakan perintah suci dari Allah swt. melalui alQur'an serta diturunkan kepada nabi-Nya yang terakhir yaitu Muhammad swt. ${ }^{19}$

Deklarasi tersebut kemudian disampaikan dalam suatu konferensi Internasional Hak Asasi Manusia di Wina, Austria pada tahun 1993 oleh Menteri Luar Negeri Arab Saudi yang menegaskan bahwa deklarasi ini merupakan konsensus dunia Islam tentang hak asasi manusia. ${ }^{20}$ Dalam kesempatan pertemuan Organisasi Konferensi Islam di Teheran pada Desember tahun 1997, Iran dan sejumlah Negara Organisasi Konferensi Islam lainnya tetap terus menyampaikan gagasan bahwa sistem hak asasi manusia Perserikatan Bangsa-Bangsa yang ada sangat diwarnai oleh barat dan penyesuaian agar mampu mengakomodasi budaya dan nilai-nilai religius negara-negara muslim. ${ }^{21}$ Deklarasi ini diharapkan dapat berkontribusi bagi umat manusia dalam upaya penegasan hak asasi manusia, baik untuk melindungi manusia dari perdagangan manusia, penganiayaan dan menegaskan kebebasan serta hak manusia atas kehidupan yang bermartabat berdasarkan Syariat Islam. ${ }^{22}$

Banyak tokoh-tokoh muslim yang sangat berkontribusi dalam penyebaran hak asasi manusia di dunia Islam di antaranya, di Mesir dikenal Syekh Rafi'ah Rafi' at-Tahtawi (1801 sampai 1873). Salah satu negara yang hingga kini masih mempertahankan hak asasi manusia berdasarkan pada Syariah Islam yaitu Arab Saudi. ${ }^{23}$ selain Arab Saudi, Republik Islam Iran juga melakukan hal yang

\footnotetext{
${ }^{18}$ Pasal 1 Undang-Undang Nomor 39 Tahun Tentang Hak Asasi Manusia.

${ }^{19}$ Sunaryo, "Studi Komparatif Antara the Declaration Of Human Right 1948 dan the Cairo Declaration Of Human Right 1990”, h. 390. http://Jurnal.Fh.Unila.Ac.Id/Index.Php/Fiat/Article/View/ 61/0\&Ved (Diakses 24 Maret 2018).

${ }^{20}$ Abu Ishaq Ibrahim Al-Syatibi, Al-Muwafaqat Fi Usul Al-Syari'ah, Juz 1 (Beirut: Dar Al-Kutub Al-Ilmiyyah, t.th), h. 54.

${ }^{21}$ Ann Elizabeth Mayer, Islam and Human Right: Tradition and Politics, h. 22.

${ }^{22}$ Naylin Najihah, Deklarasi Oki Di Kairo, www.Academia.Edu/10452815/Deklarasi_ Kairo_Translated_By_Naylin_Najihah_\&Ved (Diakses 26 Maret 2019).

${ }^{23}$ Taufik Abdullah, Ensiklopedia Tematis Dunia Islam, h. 165
} 
sama. ${ }^{24}$ Sejak adanya revolusi Islam Iran pada awal tahun 1979, Pemerintah Islam Iran memproklamasikan diterapkannya syariat Islam sebagai dasar negara. ${ }^{25}$

Dalam the Cairo Declaration of Human Right disebutkan hak asasi manusia meliputi hak untuk hidup, hak berkeluarga dan melanjutkan keturunan, hak atas kekayaan intelektual, hak kebebasan berpendapat dan memperoleh keadilan, hak kebebasan beragama, hak atas kemerdekaan diri, hak kebebasan berdomisili dan memperoleh suaka negara lain, hak atas rasa aman, hak atas kesejahteraan, hak kepemilikan, hak turut serta dalam pemerintahan, hak perempuan dan hak anak. ${ }^{26}$

\section{c. Sumber the Universal Declaration of Human Right (UDHR) dan the Cairo Declaration of Human Right (CDHR)}

Sumber dan inspirasi dalam pembentukan the Universal Declaration of Human Right yaitu sebagai berikut 27

a) Piagam Perserikatan Bangsa-Bangsa

b) Magna Charta (1215)

c) Bill of Rights (1689)

d) The Declaration of Independence, the United States of America (1776)

e) Declaration of the Right of Man and the Citizen, Prancis (1789)

The Cairo Declaration of Human Right merumuskan poin-poin hak asasi manusia dalam perspektijf nilai-nilai ajaran Islam. Dalam deklarasi ini, terdapat sekitar dua puluh lima pasal yang sebagian besar mengutip dari al-Qur'an, sebagai dasar acuan dan sumber-sumber ajaran nilai-nilai Islam. ${ }^{28}$

Selain bersumber pada al-Qur'an, hak asasi ini juga bersmber pada Sunnah Nabi saw. pengalaman Nabi dalam membina kehidupan sosial dan politik yang harmonis dengan keberagaman komunitas agama. ${ }^{29}$ Sehingga dapat diketahui bahwa meskipun the Cairo Declaration of Human Right baru dideklarasikan pada tanggal 15 Agustus 1990, namun sumber dan referensinya

${ }^{24}$ Arzoo Osaloo, "The Measure Of Mercy: Islamic Justice, Sovereign Power and Human Rights In Iran”, Cultur Anthropology, vol. 21 no. 4. http:www.neliti.com/journals/sinergi-jurnal-teknik-mercbuana\%3D4\&ved (Diakses 26 Maret 2019).

${ }^{25}$ Abdullah A. Al-Naim, "Human Right In The Arab World: A Regional Perspective", Human Rights Querterly, vol. 23 no. 3. http://eprints.walisongo.ac.id/9152/1/122211003.pdf\&ved (Diakses 26 Maret).

${ }^{26}$ Ann Elizabeth Mayer, Islam and Human Raight: Traditian And Politics, Edisi Ketiga (Colorado: Westview Press, 1999), h. 203-208.

${ }^{27}$ Icha's World, Ham: Universal Declaration of Human Right). http:/(Www.Google.Com/ Amp/S/Ichaimucu.Wordpress.Com/2011/03/02/Ham-Universal-Declaration-Of-Human-Right-1948/ Amp/ (Diakses 27 Maret 2019).

${ }^{28}$ Martinus Sardi, Mengenal Hak Asasi Manusia dalam Islam Berdasarkan Deklarasi Kairo, h. 390. http://repository.imy.ac.id/bitstream/handke/123456789/3914Martinus\%2529Sardi\%_Mengen al\%2520HAM\%dalam\%2520Islam\%2520\%Berdasarkan\%Deklarasi\%2510\% Kairo.pdf\%3Fsequence \%3D1\&ved (Diakses 29 Maret 2019).

${ }^{29}$ Ali Syari'at, Rasulullah Hijrah Hingga Wafat Tinjauan Kritis Sejarah Nabi Periode Madinah (Cet. II; Bandung: Pustaka Hiayah, 1995), h. 30-39. 
telah ada sejak empat belas abad sebelumnya. ${ }^{30}$

\section{Deskripsi Penerapan the Universal Declaration of Human Right (UDHR) dan the Cairo Declaration of Human Right (CDHR) Di Indonesia}

Indonesia telah meratifiksi the Universal Declaration of Human Right yang diikuti oleh negara-negara di dunia yang tergabung di dalam Perserikatan Bangsa-Bangsa pada 10 November 1948 ke dalam Undang-Undang Nomor 39 Tahun 1999 Tentang Hak Asasi Manusia. Undang-Undang Nomor 39 Tahun 1999 Tentang Hak Asasi Manusia yang terdiri atas dua bab yaitu bab satu tentang ketentuan umum dan bab dua tentang asas-asas dasar menjadi jawaban akan kebutuhan masyarakat Indonesia baik di tingkat nasional maupun internasional. Sebagaimana disebutkan pada dasar pemikiran Undang-undang nomor 39 tahun 1999 pada poin b yang berbunyi "Bangsa Indonesia sebagai anggota Perserikatan Bangsa-Bangsa mengembang tanggung jawab moral dan hukum untuk menjunjung tinggi dan melaksanakan Deklarasi Universal tentang hak asasi manusia yang ditetapkan oleh Perserikatan Bangsa-Bangsa serta sebagai instrumen internasional lainnya mengenai hak asasi manusia yang telah diterima oleh Negara Repubik Indonesia. ${ }^{31}$ Sedangkan di dalam Undang-Undang Dasar 1945 (hasil amandemen kedua tahun 2000), masalah mengenai hak asasi manusia dicantumkan secara khusus dalam Bab X pasal 28 A sampai Pasal 28 J. 32

Dari kedua instrumen tersebut, dapat diketahui bahwa kedudukan hak asasi manusia di Indonesia merupakan sebuah perangkat yang melekat pada hakikat dan keberadaan manusia sebagai makhluk Tuhan Yang Maha Esa dan anugerah yang wajib dihormati, dijunjung tinggi dan dilindungi oleh individu dan negara. Namun, perlu digarisbawahi bahwa manusia tidak hanya memiliki hak asasi tetapi juga memiliki kewajiban dasar sebagai penyeimbang dari pelaksanaan dan penegakan hak asasi manusia. ${ }^{33}$

Deklarasi Universal Hak-Hak Asasi Manusia bagi Negara Indonesia telah ada dari zaman dahulu namun baru di ikrarkan pada pedoman dasar negara yaitu Undang-Undang Dasar 1945, yang di dalamnya terdapat hak-hak asasi manusia sebagai makhluk pribadi maupun makhluk sosial. Selain itu, dipertegas dalam Pancasila dari sila pertama sampai sila kelima.

Hak asasi manusia yang terdapat dalam the Cairo Declaration of Human Right memuat prinsip-prinsip untuk menjaga kehormatan dan hak-hak

${ }^{30}$ Izzuddin Washil dan Ahmad Khoirul Fata, "Ham Islam dan Duham PBB: Sebuah Ikhtiar Mencari Titik Temu”, MIQOT, Vol. XLI no. 2 (Juli-Desember 2017), h. 437. http://media. nelti.com/ media/publications/255994-ham-islam-dan-duham-pbb-sebuah-ikhtiar-mencari-titik-temuc27746c.pdf \&ved (Diakses 29 Maret 2019).

${ }^{31}$ Abdul Wahid dan Muhammad Irfan, Perlindungan Terhadap Korban Kekerasan Seksual (Cet. 2; Bandung: PT. Refika Aditama), h. 9.

${ }^{32}$ Muhammad Luthfan Setiaji dan Aminullah, "Kajian Hak Asasi Manusia dalam Negara The Rule Of Law: Antara Hukum Progresif dan Hukum Positif”, h.70. www.Google.Com (Diakses 29 Maret 2019).

${ }^{33}$ Meilanny Budiarti Santoso, "LGBT Dalam Perspektif Hak Asasi Manusia”, Sosial Work Journal, vol. 6 no. 2 (2016), h. 227. http://jurnal.unpac.id.ac.id/sh are/ article/download/13206/6036\& ved (Diakses 29 Maret 2019). 
manusia. Hak asasi manusia dalam Islam bukan hanya dimiliki oleh individu secara ekslusif dan tanpa batas, sebab hak dalam Islam tidak lepas dari kewajiban. Manusia memang berhak untuk menjalani kehidupan sesukanya, namun tidak diperbolehkan menganiaya dirinya sendiri apalagi orang lain. ${ }^{34}$

Hampir setiap negara memiliki permasalahan dalam penegakan hak asasi manusia, tidak terkecuali Indonesia. Masalah penegakan hak asasi manusia selalu beriringan dengan penegakan hukum. ${ }^{35}$ Faktor-faktor penyebab sulitnya penegakan hak asasi manusia di Indonesia antara lain, penegak hukum yang belum mampu memberikan perlindungan kepada korban hak asasi manusia, konsep dan standarisasi, media kurang mendukung pemberitaan tentang hak asasi manusia, pelayanan publik belum optimal, adat istiadat terkadang melegalkan kekerasan, persoalan kemiskinan, interpretasi yang keliru pada ajaran agama, yang semua itu terbungkus dalam budaya patriarki. ${ }^{36}$

\section{Perilaku Seksual Transgender Dalam Perspektif the Universal Declaration of Human Right (UDHR)}

Banyak ditemukan di masyarakat dalam berbagai kalangan, perempuan yang berperan, berdandan dan memiliki kegemaran layaknya laki-laki pada umumnya ataupun sebaliknya seorang laki-laki yang memiliki kecenderungan berperan, berdandan dan memiliki kegemaran layaknya seorang perempuan. ${ }^{37}$ Penyebab penyakit transgender sangatlah kompleks, salah satunya karena kelainan genetik, tetapi pengaruh lingkungan terutama penggunaan obat-obat hormonal pada masa kehamilan yang mengakibatkan terjadinya ambiguitas seksual pada bayi perempuan. Selain itu juga dipengaruh oleh faktor psikis dan lingkungan. Faktor inilah yang paling dominan mempengaruhi, pertama lingkungan pergaulan dan didikan perilaku yang tidak tepat.

Berbagai penelitian dilakukan oleh para akademis dan aktivis hak asasi manusia yang menghasilkan sikap pro dan kontra terhadap perilaku seksual yang menyimpang tersebut. Perdebatan pendapat dengan argumentasiargumentasi yang berlandaskan pada perspektif hak asasi manusia dan perspektif agama. Pihak yang mendukung perilaku seksual menyimpang tersebut, kerap menjadikan hak asasi manusia sebagai perisai pelindung kepentingan mereka. Bahwasanya kaum transgender adalah manusia yang juga memiliki hak dan kesempatan yang sama serta tidak boleh diperlakukan secara diskrimanitif hanya karena orientasi seksual mereka. ${ }^{38}$

Isu transgender yang telah berada pada taraf globalisasi, berkat keberhasilan penyebaran melalui serangkaian gerakan pro-lesbian, gay, biseksual

\footnotetext{
${ }^{34}$ Hamid Fahmi Zarkasyi, Islam Ham dan Keberagaman Agama (Jakarta: INSISTS, 2011), h. 15.

${ }^{35}$ Bambang Heri Supriyanto, Penegakan Hukum Mengenai Hak Asasi Manusia (Ham) Menurut Hukum Positif Di Indonesia, h.152. www.Google.Com (Diakses 01 April 2019).

${ }^{36}$ Agus Dedi Putrawan, Membumikan Deklarasi Kairo Di Indonesia, h. 183. www.Google. Com (Diakses 01 April 2019).

${ }^{37}$ Krista Marsha Esterlita, Dilema Pengungkapan Identitas Wanita Transeksual: Kajian Fenomonologi Wanita Transeksual Di Surabaya.

${ }^{38}$ Roby Yansyah dan Rahayu,"Globalisasi Lesbian, Gay, Biseksual dan Tansgender (Lgbt): Perspektif Ham dan Agama", Journal Law Reform, vol. 14 no. 1 (2018), h.137. https://Ejournal.Undip.Ac.Id/Index.Pp/Lawreform/Article/Wiew/20242 (Diakses 20 April 2019).
} 
dan transgender. Dengan di dukung adanya deklarasi Hak Asasi Manusia universal (the Universal Declaration of Human Right) tahun 1948 yang di salahpahami keberadaannya sebagai proses liberalisasi dan kebebasan mengekspresikan diri. Di beberapa negara, kampanye hak lesbian, gay, biseksual dan transgender yang dibingkai sebagai bagian dari perjuangan hak asasi manusia yang diakui secara internasional. Dengan fakta bahwa dalam the Universal Declaration of Human Right 1948 tidak ada pasal yang secara khusus yang mengatur tentang orientasi seksual kepada lawan jenis, memungkinkan hak kaum transgender masih dapat diperdebatkan. Dalam the Universal Declaration of Human Right tahun 1948 tidak ada pasal yang menyebutkan orientasi seksual, namun ada beberapa pasal yang menyangkut hak asasi manusia untuk menikah dan membangun keluarga. Pasal tersebut dapat dijadikan dasar bagi kaum transgender sebab pernikahan adalah cara yang legal dalam mengekspresikan orientasi seksual yang menjadi tujuan akhir bagi setiap pasangan. ${ }^{39}$

Pasal 16 the Universal Declaration of Human Right tahun 1948 menyatakan bahwa:

(1) Man and women of full age, without any limitation due to rac, nationality or religion, have the right to marry and to found a family. The are entitled to equal rights as to marriage, during marriage and at its dissolution.

(2) Marriage shall be entered into only with the free and full consent of the intending spouses.

(3) The family is the natural and fundamental group unit of society and is entitled to protection by society and the state. ${ }^{40}$

Artinya:

(1) Laki dan perempuan yang sudah dewasa, dengan tidak di batasi kebangsaan, kewarganegaraan atau agama, berhak untuk menikah dan membentuk keluarga. Mereka mempunyai hak yang sama dalam soal perkawinan, di dalam masa perkawinan dan di saat perceraian.

(2) Perkawinan hanya dapat dilaksanakan berdasarkan pilihan bebas dan persetujuan penuh oleh kedua mempelai.

(3) Keluarga adalah unit kelompok masyarakat yang alami dan asasi yang berhak mendapatkan perlindungan dari masyarakat dan negara.

Dalam pasal 2 the Universal Declaration of Human Right tahun 1948 juga menyatakan bahwa:

Everyone is entitled to all the rights and freedoms set forth in this declaration, without distinction of an kind, such as race, colour, sex, languange, religion, political or other opinion, national or social origin, birth or other status. Furthmore, no distiction shall be made on the basis of the political, jurisdoctional

\footnotetext{
${ }^{39}$ Robi Yansyah dan Rahayu, "Globalisasi Lesbian, Gay, Biseksual dan Tansgender (Lgbt); Perspektif Ham dan Agama", Journal Law Reform, vol. 14 no. 1 (2018), h.137. https://Ejournal.Undip.Ac.Id/Index.Pp/Lawreform/Article/Wiew/20242, h.135 (Diakses 24 April 2019).

${ }^{40}$ Sunaryo, "Studi Komparatif Antara The Universal Declaration Of Human Right 1948 Dan The Cairo Declaration Of Human Right In Islam 1990”, Fiat Justitia Ilmu Hukum, vol. 5 no. 2 (2012), h.349. Jurnal.Fh.Unila.Ac.Id/Index.Php/Fiat/Article/View/61 (Diakses 24 April 2019).
} 
or internatonal status of the country or territory to wich a person belongs, whether it be independent, trust, nonself-governing or under an other limitation of sovereignty. 41

Artinya:

Setiap orang berhak atas semua hak dan kebebasan-kebebasan yang tercantum di dalam Deklarasi ini dengan tidak ada pengecualian apa pun, seperti perbedaan ras, warna kulit, jenis kelamin, bahasa, agama, plitik atau pandangan-pandangan lain asal-usul kebangsaan atau kemasyarakatan, hak milik, kelahiran ataupun kedudukan lain.

Dalam the Universal Declaration of Human Right tahun 1948 memang tidak ada pasal yang mengatur bahwa ketentuan orientasi seksual pria harus kepada wanita ataupun sebaliknya, namun hal tersebut bukan berarti dengan serta merta bahwa perilaku seksual menyimpang kaum transgender harus diperbolehkan dan mendapatkan dukungan. Dalam The Universal Declaration of Human Right 1948 juga mengatur pembatasan, dalam pasal 29 ayat 2.

Selain itu, the Universal Declaration of Human Right tahun 1948 juga menjamin hak setiap orang untuk percaya pada ajaran agamanaya dan mempraktikkan ajaran agamanya tersebut dengan baik. Dalam pasal 18 the Universal Declaration of Human Right tahun 1948 menyatakan bahwa:

Everyone has the right includes freedom of thought, conscience and religion, this right includes freedom to cange his religion or beliefe, and freedom, either alone or in community with others and in public or private, to manifest his religion or belief in teaching, practice, worship and observance. ${ }^{42}$

Artinya:

Setiap orang berhak atas kebebasan mempunyai dan mengeluarkan pendapat; dalam hal ini termasuk kebebasan menganut pendapat gangguan, dan untuk mencari, menerima dan menyampaian keteranganketerangan dan pendapat dengan cara apa pun dan dengan tidak memandang batas-batas.

Indonesia sebagai negara yang mengakui keberadaan hak asasi manusia yang harus dihormati dan dilindungi, Bab XI Undang-Undang Dasar Negara Republik Indonesia Tahun 1945 merupakan bab yang secara khusus mengatur tentang Hak Asasi Manusia di Indonesia secara umum. Undang-Undang Dasar Negara Republik Indonesia Tahun 1945 secara hierarki merupakan peraturan perundang-undangan tertinggi yang menjadi acuan peraturan perundangundangan lain di bawahnya, sehingga tidak akan ada peraturan di Indonesia yang tidak mengakui hak asasi manusia. Selain itu, Indonesia juga mengakui keberadaan the Universal Declaration of Human Right 1948 yang menjadi

${ }^{41}$ Sunaryo, "Studi Komparatif Antara The Universal Declaration Of Human Right 1948 Dan The Cairo Declaration Of Human Right In Islam 1990”, Fiat Justitia Ilmu Hukum, vol. 5 no. 2 (2012), h.349. Jurnal.Fh.Unila.Ac.Id/Index.Php/Fiat/Article/View/61 (Diakses 24 April 2019).

${ }^{42}$ Sunaryo, "Studi Komparatif Antara The Universal Declaration Of Human Right 1948 dan The Cairo Declaration Of Human Right In Islam 1990”, Fiat Justitia Ilmu Hukum, vol. 5 no. 2 (2012), h. 403. Jurnal.Fh.Unila.Ac.Id/Index.Php/Fiat/Article/View/61 (Diakses 24 April 2019). 
instrumen hukum internasinal yang diakui oleh bangsa-bangsa di dunia. Pengambilan sikap Indonesia terhadap perilaku seksual menyimpang kaum transgender yang melakukan perbuatan tersebut dilandasi dengan asas kebebasan hak asasi manusia menjadi permasalahan penting yang segera membutuhkan solusi. Indonesia sebagai negara yang masih kental dengan ajaran agama, moral dan etika yang telah berkembang dan mengakar di seluruh lapisan masyarakat, tentu saja dengan tegas menolak menerima pelaku dan perilaku seksual menyimpang tersebut dengan berbagai alasan yang didasari atas ajaran agama maupun budaya. ${ }^{43}$

Dalam Undang-Undang Nasional Indonesia, pasal $28 \mathrm{j}$ Undang- Undang Dasar, pasal 69 ayat 1 dan 73 Undang-undang Hak Asasi Manusia Nomor 39 Tahun 1999, telah ditentukan pembatasan yang intinya bahwa setiap orang memilki hak asasi manusia juga menghormati hak asasi manusia orang lain, menghormati pembatasan yang ditentukan oleh undang-undang, memenuhi persyaratan moral, etika, tata tertib kehidupan masyarakat, berbangsa dan bernegara, nilai-nilai agama, serta menjaga kemanan dan ketertiban umum masyarakat demokratis. ${ }^{44}$

\section{Perilaku Seksual Transgender dalam Perspektif the Cairo Declaration of Human Right (CDHR)}

Tindakan yang berhubungan dengan seksualitas dalam al-Qur'an dianggap sebagai sesuatu yang sangat agung, sebagai penyambung kehidupan, pengganda kehidupan, pengabadian ciptaan. Fungsi seksual itu sendiri merupakan fungsi yang suci atau sakral, yang menjadi pertanda (ayat) kekuasaan Tuhan. ${ }^{45}$ Pandangan Islam tentang seks, merupakan pandangan yang menyeluruh, yang bertujuan untuk mengintegrasikan seks dalam kehidupan sehari-hari. 46

Dalil -dalil syar'i yang mengharamkan operasi jenis kelamin antara lain sebagai berikut:

QS. An-Nisa/4:119:

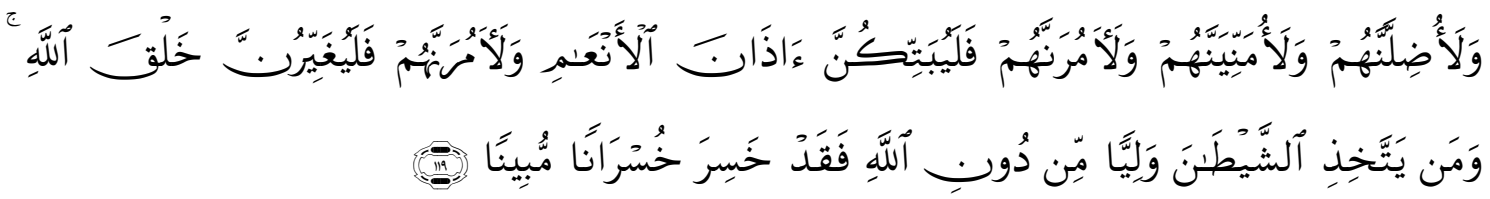

Terjemahnya:

Dan aku benar-benar akan menyesatkan mereka, dan akan membangkitkan anganangan kosong pada mereka dan akan menyuruh mereka (memotong telinga-telinga

\footnotetext{
${ }^{43}$ Roby Yansyah dan Rahayu, "Globalisasi Lesbian, Gay, Biseksual dan Tansgender (Lgbt): Perspektif Ham dan Agama”, Journal Law Reform, vol. 14 no. 1 (2018), h.137. https://Ejournal.Undip.Ac.Id/Index.Pp/Lawreform/Article/Wiew/20242 (Diakses 25 April 2019).

${ }^{44}$ Roby Yansyah dan Rahayu, "Globalisasi Lesbian, Gay, Biseksual dan Transgender (Lgbt): Perspektif Ham dan Agama", Journal Law Reform, vol. 14 no. 1 (2018), h.138, https://Ejournal.Undip.Ac.Id/Index.Pp/Lawreform/Article/Wiew/20242 (Diakses 25 April 2019).

${ }^{45}$ Abdelwahab Bouhdiba, Sexualitity In Islam:Peradaban Kamasutra Abadi Pertengahan (Cet. I; Jogjakarta: Aleniia, 2004), h. 31

${ }^{46}$ Abdelwahab Bouhdiba, Sexualitity In Islam:Peradaban Kamasutra Abadi Pertengahan, h.207.
} 
binatang ternak), lalu mereka benar-benar memotongnya, dan akan aku suruh mereka (mereka mengubah ciptaan Allah), lalu benar-benar mereka mengubahnya. "Barang siapa yang menjadikan setan menjadi pelindung selain Allah, maka sesungguhnya dia menderita kerugian yang nyata. ${ }^{47}$

Ayat ini membahas tentang larangan merubah ciptaan Allah. Penggalan ayat "...falayugayyirunna khalqallah ..." menegaskan bahwa yang di maksud dengan merubah ciptaan tuhan termasuk menusuk mata unta yang telah berlarut-larut mereka kendarai, atau memberi tato sebagai hiasan. Tetapi hakikanya adalah memperburuk wajah atau bentuk tubuh. Termasuk juga dalam pengertian merubah ciptaan Allah adalah mengebiri, homoseksual dan lesbian serta praktik-praktik yang tidak sesuai dengan fitrah manusia. ${ }^{48}$

Islam telah mengatur bagaimana tatacara menyalurkan atau mengespresikan orientasi seksual dengan perilaku seksual yang benar. Dalam Al-Qur'an ditemukan banyak perintah agar manusia menjaga kemaluannya serta menyalurkan hasrat seksual hanya dengan cara yang dibenarkan syar'i, sebagaiamana dijelaskan dalam firman Allah QS. an-Nur/24: 30-31.

Perilaku seksual pada sesama jenis atau homoseksual yang sudah diharamkan oleh Allah swt. tersebut telah terjadi pada kaum Nabi Luth as. perilaku seksual tersebut adalah bentuk penyaluran syahwat biologis bukan pada tempat yang wajar, yaitu kepada sesama jenis. Selain terdapat dalam alQur'an, larangan melakukan hubungan sesama jenis juga terdapat dalam hadis Nabi saw. yang diriwayatkan oleh Imam Ahmad dari Ibnu Abbas ra., sebagai berikut:

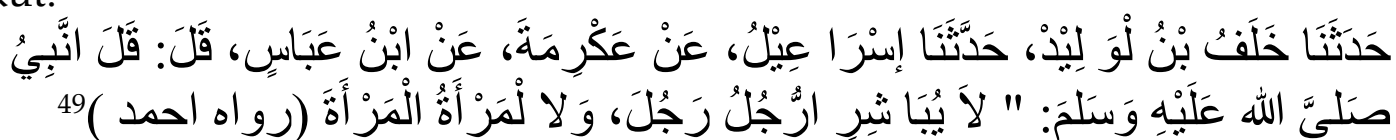

Artinya:

Telah menceritakan kepada kami khalaf bin al walid telah menceritakan kepada kami israil dari simak dari ikrimah dari ibnu abbas, ia berkata : nabi shallahu 'alaihi wasallam bersabda: "janganlah laki-laki bercumbu dengan sesama laki-laki dan perempuan bercumbu dengan perempuan di larang dalam syariat Islam. (HR. Ahmad)

Dari redaksi teks hadis di atas, maka dapat di tarik kesimpulan hubungan seksual antara sesama jenis dalam hal ini laki-laki dengan laki-laki serta perempuan dengan perempuan di larang dalam syariat Islam. Hubungan antara sesama jenis atau homoseksual adalah perilaku seksual yang paling buruk dan terkutuk yang telah menyalahi aturan Allah dan menyimpang dari fitrah manusia yang lurus. Mengingat yang seharusnya seorang laki-laki berpasangan dengan perempuan secara sah, bukan bergaul dengan sesama jenis.

Dalam perkembangan kehidupan dunia modern, hubungan seksual tidak saja terjadi dengan lawan jenis, tetapi terjadi pula dengan sesama jenis yang

\footnotetext{
${ }^{47}$ Kuthbuddin Aibak, Kajian Fiqh Kontemporer (Yogyakarta: Teras, 2009), h. 133.

${ }^{48}$ Quraish Shihab, Tafsir Al-Misbah (Jakarta: Lentera Hati, 2002), h. 722.

49 Abu Abdillah Ahmad Bin Muhammad Bin Hanbal, Musnad Al-Imam Ahmad Bin Hanbal (t.tp: Muassasah Al-Risalah, 2001), h. 494.
} 
dikenal dengan istilah homoseksual bagi kaum pria dan lesbi bagi kaum perempuan. Bahkan seseorang dapat melakukan hubungan ganda yang dikenal dengan istilah biseksual. ${ }^{50}$

Kehadiran mereka di tengah-tengah masyarakat menjadi lahan perdebatan, pro dan kontra dalam menyikapi keberadaan mereka. Kelompok yang pro berargumentasi bahwa keberadaan kaum transeksualitas adalah fakta sosial yang ada di tengah-tengah masyarakat. ${ }^{51}$ Sedangkan kelompok yang kontra beralasan bahwa perilaku tersebut menyimpang dari agama dan abnormal. 52

Deklarasi kairo (the Cairo Declaration of Human Right) yang dijadikan prinsip bagi negara-negara yang tergabung dalam Organisasi Konferensi Islam dalam melaksanakan hak asasi manusia berdasarkan syariat. Dalam deklarasi kairo tidak ada pasal yang secara khusus mengatur tentang orientasi seksual, akan tetapi ada beberapa pasal yang mengatur tentang perkawinan yang dapat dijadikan landasan ketidak bolehanya perilaku seksual menyimpang kaum transgender.

Dalam pasal 5 the Cairo Declaration of Human Right tahun 1990 menyatakan bahwa:

(1) The family is the foundation of society, and marriage is the basis of making a family. Men and women have to the right to marriege, and no restrictionc stemming from race, colour or nationalitty shall prevent them from exercising this right.

(2) The society and the state shall remove all obstacle to marriage and facilitate it, and shall protect the family and safeguard its welfare. ${ }^{53}$

Artinya:

(1) Keluarga adalah pondasi dari masyarakat dan pernikahan adalah dasar formasinya. Lelaki dan perempuan memiliki hak untuk menikah dan tidak ada larangan yang membatasi ras, warna kulit dan kenegaraan yang menghalangi mereka dari penggunaan hak tersebut.

(2) Masyarakat dan negara harus menghapus hambatan-hambatan dalam pernikahan dan seharusnya memfasilitasi prosedur pernikahan tersebut. Mereka menjamin perlindungan dan kesejahteraan keluarga.

Penjelasan dalam pasal ini menggunakan acuan Syariah Islam, sebagaimana dinyatakan dalam pasal 25 the Cairo Declaration of Human Right tahun 1990 sebagai brikut:

"The Islamic shariah is only source of reference for the explaination or

\footnotetext{
${ }^{50}$ Abdul malik gozali, Lgbt Dalam Perspektif Ham dan Doktrin Agama: Solusi dan Pencegahan, h.31

${ }^{51}$ The Handbook Of Lesbian, Gay, Biseksual, And Transgender Public Health: A Practitioner's Guide To Service ( Haworth Press, 2006). (Di Akses 27 April 2019).

${ }^{52}$ A. Supratiknya, Mengenal Perilaku Abnormal (Yogyakarta: Kanisius, 1999), h. 94.

${ }^{53}$ Sunaryo, "Studi Komparatif Antara The Universal Declaration Of Human Right 1948 dan The Cairo Declaration Of Human Right In Islam 1990”, Fiat Justitia Ilmu Hukum, vol. 5 no. 2 (2012), h. 393. Jurnal.Fh.Unila.Ac.Id/Index.Php/Fiat/Article/View/61 (Diakses 27 April 2019).
} 
clarification of any of the articles of this declaration". 54

Artinya:

"Syariat Islam adalah satu-satunya sumber acuan bagi penjelasan isi paal-pasal yang diatur didalamnya".

Konsep dasar seksual dijelaskan dalam surah al-Najm/53: 45:

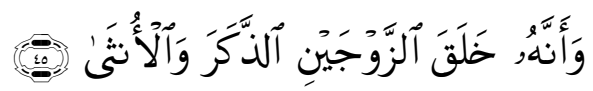

Terjemahnya:

Dan bahwasanya Dialah yang menciptakan kedua pasangan, laki-laki dan perempuan. 55

Tafsiran kata zaujani yaitu pasangan yang terdiri dari jenis kelamin lakilaki dan perempuan. ${ }^{56}$ Itu artinya tidak ada peluang bagi suami istri dari sesama jenis ataupun percampuran dengan jenis kelamin yang abal-abal.

Dijelaskan juga dalam QS al-Nur/24: 30-31 yang telah disebutkan pada pembahasan sebelumnya pada halaman 54 .

Setiap orang diberi hak dan kebebasan, namun the Cairo Declaration of Human Right tahun telah memberikan pembatasan-pembatasan terhadap hak dan kebebasan tersebut sesuai yang telah ditetapkan oleh syariah Islam. Hal ini di atur dalam pasal 24 bahwa:

"All the rights and freedoms in this declaration are subject to Islam Sharia"

Artinya:

"Semua hak dan kebebasan yang dinyatakan di dalam Deklarasi ini tunduk kepada Syariat Islam".

Dalam perundang-undangan nasional di Indonesia, yaitu UndangUndang Nomor 1 Tahun 1974 pasal 6 sampai 12 dan Kompilasi Hukum Islam pasal 14. Meskipun pada hakikatnya tidak ada satupun yang menyebutkan atau mensyaratkan bahwa suatu perkawinan itu harus dilakukan oleh laki-laki dengan perempuan. Sebab yang menjadi syarat adalah adanya calon sumai dan calon istri atau kedua mempelai. Akan tetapi, ketika dikatakan calon suami maka secara otomatis akan muncul anggapan bahwa dia adalah laki-laki. Begitu juga sebaliknya, bila dikatakan calon istri maka anggapan bahwa dia adalah perempuan akan muncul dengan sendirinya. ${ }^{57}$

\section{Analisis Komparatif}

Transgender dikenal sebagai bentuk paling ekstrim dari pengubahan atau pertukaran gender. Hal ini disebabkan karena keinginan mereka tidak hanya

\footnotetext{
${ }^{54}$ Sunaryo, "Studi Komparatif Antara The Universal Declaration Of Human Right 1948 dan The Cairo Declaration Of Human Right In Islam 1990”, Fiat Justitia Ilmu Hukum, vol. 5 no. 2 (2012), h. 406. Jurnal.Fh.Unila.Ac.Id/Index.Php/Fiat/Article/View/61 (Diakses 27 April 2019).

${ }^{55}$ Kementrian Agama, Al-Qur'am dan Terjemahannya (Cet 1; Solo: PT. Tiga Serangkai Pustaka Mandiri, 2013), h. 528.

${ }^{56}$ Abi' Abdillah Muhammad Bin Ahmad Bin Ali Galib Bin Athiyyah Aal-Andalusi, Al-Muharram Al-Wajis Fi Tafsir Al-Kitab Al-Aziz, Juz IV (Libanon: Dar Al-Kutub Al-'Ilmiyah, 2001), h.187.

${ }^{57}$ Suhaimi Razak, "Lgbt Dalam Perspektif Agama”, Madura al-ibrah, vol. 1 no. 1 (Juni 2016) Download.Garuda.Risetdikti.Go.Id, hal. 54. (Diakses 20 April 2019).
} 
sebatas berpakaian, berdandan dan bertingkahlaku sebagaimana lawan jenisnya, tetapi juga adanya keinginan untuk mengganti alat kelamin mereka melalui operasi agar sesuai dengan kepribadian atau jiwa yang mereka miliki. ${ }^{58}$

Berbagai penelitian yang dilakukan oleh para akademis dan aktivitas hak asasi manusia yang menghasilkan sikap pro dan kontra terhadap perilaku seksual yang menyimpang tersebut. Fakta yang terdapat dalam Deklarasi Universal Hak Asasi Manusia yaitu baik dalam deklarasi hak asasi manusia universal (the Universal Declaration of Human Right) tahun 1948 yang dipelopori oleh Perserikatan Bangsa-Bangsa dan Hak Asasi Manusia versi Islam (the Cairo Declaration of Human Right) yang melaksanakan hak asasi manusia berdasarkan pada acuan syariat sama sekali tidak ada yang mengatur secara khusus tentang orientasi seksual kepada lawan jenis. Hal ini memungkinkan hak kaum transgender masih dapat diperdebatkan.

Meskipun demikian, ada beberapa pasal yang menyangkut hak asasi manusia untuk menikah dan membangun keluarga baik dalam the Universal Declaration of Human Right Tahun 1948 dan the Cairo Declaration of Human Right Tahun 1990. Dalam the Universal Declaration of Human Right tahun 1948 hak asasi manusia untuk menikah dan membangun keluarga diatur dalam pasal 16.Pasal ini dijadiakan dasar bagi kaum transgender untuk membenarkan dan melegalkan perilaku seksual mereka yang menyimpang tersebut sebab pernikahan adalah cara yang legal dalam mengekspresikan orientasi seksual mereka tanpa aturan tegas bahwa orintasi seksual pria harus kepada wanita ataupun sebaliknya. Yang kemudian diperkuat oleh pasal 2.

Namun perlu diketahui bahwa memang dalam the Universal Declaration of Human Right tahun 1948 tidak ada pasal yang mengatur bahwa orientasi seksual pria harus kepada wanita ataupun sebaliknya, hal tersebut bukan berarti bahwa perilaku seksual menyimpang kaum transgender diperbolehkan dan mendapatkan dukungan. Dalam the universal declaration of human right tahun 1948 pasal 29 ayat 2 juga mengatur pembatasan.

Pada pasal 29 ayat 2 di jelaskan bahwa dalam menjalankan hak-hak dan kebebasannya, setiap orang harus tunduk hanya pada pembatasan-pembatasan yang ditetapkan oleh undang-undang yang tujuannya semata-mata untuk menjamin pengakuan serta penghormatan yang tepat terhadap hak-hak dan kebebasan-kebebasan orang lain, dan untuk memenuhi syarat-syarat yang adil dalam kesusilaan, ketertiban dan kesejahteraan umum dalam masyarakat yang demokratis. ${ }^{59}$

Selain itu, the Universal Declaration of Human Right tahun 1948 juga menjamin hak setiap orang untuk percaya pada ajaran agamanaya dan mempraktikkan ajaran agamanya tersebut dengan baik. Tidak ada ajaran agama yang ada di dunia ini yang membolehkan praktik perilaku seksual menyimpang yang dilakukan oleh kaum transgender. Hal ini dijelaskan dalam

\footnotetext{
${ }^{58}$ Yash, Transeksualisme: Sebuah Studi Kasus Perkembangan Transeksual Perempuan Ke LakiLaki (Semarang: CV AINI, 2003), h.33.

${ }^{59}$ Naskah the Universal Declarartion of Human Right
} 
pasal 18 the Universal Declaration Of Human Right.

Sedangkan dalam the Cairo Declaration Human Right pasal yang mengatur tentang perkawinan yaitu pasal 5, yang diperkuat oleh pasal 25 yang menjelaskan bahwa dalam penjelasan atau uraian dalam setiap pasal dalam the Cairo Declaratioon Of Human Right tahun 1990 menggunakan Syariah Islam sebagai sumber acuan satu-satunya. Dalam syariah Islam Konsep dasar seksual dalam perkawinan telah dijelaskan dalam surah al-Najm/53: 45 dan surah alNur/24: 30.

Setiap orang diberi hak dan kebebasan, Namun the Cairo Declaration of Human Right tahun 1948 telah memberikan pembatasan-pembatasan terhadap hak dan kebebasan tersebut sesuai yang telah ditetapkan oleh Syariah Islam. Hal ini di atur tegas dalamm the Cairo Declaration of Human Right pasal 24.

\section{KESIMPULAN}

Kemunculan istilah Transgender di Indonesia pertama kali ditemukan pada tahun 1860 dan mengalami perkembangan pada tahun 1990-an. Pada tahun 1986 muncul istilah Wadam (Wanita Adam), namun mengalami perubahan menjadi waria (Wanita Pria). Perubahan tersebeut didasarkan pada adanya keberatan beberapa pihak dengan penggunaan nama Wanita Adam tidak sopan sebab mengandung nama Nabi Adam as. Pada tanggal 1 Maret 1982, di susul dengan pendirian Lamda sebagai organisasi gay pertama di Indonesia. pada tahun 1987 didirikan Persaudaraan Gay Nusantara sebagai penerus dari organiasi gay Lamda.

1. The Universal Declaration of Human Right dalam pasalnya tidak ada yang mengatur mengenai orienasi seksual harus kepada lawan jenis memungkinkan hak seksual transgender masih dapat diperdebatkan. Dalam the Universal Declaration of Human Right memang tidak ada yang menyebutkan tenang orientasi seksual harus kepada lawan jenis yang ada menyangkut tentang hak asasi asasi manusia untuk menikah dan membangun keluarga yaitu pasal 16 yang kemdian dijadikan dasar alasan oleh kaum transgender untuk membenarkan perilaku seksual menyimpang mereka sebab pernikahan adalah cara yang legal dalam mengekspresiakan orientasi seksualnya, sementara dalam pasal tersebut tidak dijelaskan apakah pasangannya harus lawan jenis atau sesama jenis. Meskipun dalam the Universal Declaration of Human Right tidak ada ketentuan tentang orientasi seksual seseorang harus kepada lawan jenis atau sesama jenisnya namun bukan berarti perilaku seksual dengan serta merta diperbolehkan dan mendapatkan dukungan sebab dalam pasal 2 the Universal Declaration of Human Righ juga mengatur pembatasan-pembatasan dalam pelaksanaan seseorang. Dalam pasal 2 The Universal Declaration of Human Right di sebutkan bahwa seseorang dalam menjalankan hak-haknya juga menghormati hak-hak dan kebebasan orang lain dengan tujuan 
kesejahteraan umum dan masyarakat yang demokratis. Selain itu dalam the Universal Declaration of Human Right juga terdapat pasal 18 yang menjamin hak setiap orang untuk percaya pada ajaran agamanya dan mempraktikkan ajaran agamanya tersebut dengan baik. Sementara kita ketahui bersama tidak ada ajaran agama di dunia ini yang membolehkan perilaku seksual yang menyimpang, bahkan agama yang dianggap paling toleran sekalipun.

2. The Cairo Declaration of Human Right yang landasan acuannya berdasarkan pada syariat Islam secara khusus tidak mengatur tentang otientasi seksual, namun ada pasal yang mengatur tentang perkawinan yaitu pasal 5 yang isinya mengatakan bahwa lelaki dan perempuan memiki hak untuk menikah dan tidak ada larangan yang membatasi merela yang ingin menikah untuk melaksanakan hak tersebut. Dalam pasal tersebut memang tidak menyebutkan bahwa seorang lelaki harus menikah dengan seorang wanita atau sebaliknya, namun dalam pasal 25 di jelaskan bahwa dalam menjelaskan atau menguraikan setiap pasal dalam deklarasi ini satusatunya sumber acuan yang digunakan adalah Syariah Islam. Sementara dalam Syariah Islam, perkawianan di kategorikan sebagai ibadah. Dalam QS an-Najmu/53: 45 dan QS an-Nur/ 24: 30-31 telah disebutkan konsep dasar seksual. Dalam QS al-Najmu/53: 45 pasangan suami istri disebut dengan zaujani yang maksudnya pasangan suami istri terdiri dari laki-laki dan perempuan. Artinya bahwa tidak ada peluang bagi suami istri dari jenis kelamin yang sejenis. Begitupun dalam QS an-Nur/ 24: 30-31 di sebutkan bahwa untuk para lelaki mukmin yang beriman tidak akan melepaskan nafsu birahinya kecuali kepada istrinya yang sah, bukan kepada sesama jenis yang jelas telah diharamkan.

\section{DAFTAR PUSTAKA}

Abdul Wahid dan Muhammad Irfan, Perlindungan Terhadap Korban Kekerasan Seksual (Cet. 2; Bandung: PT. Refika Aditama), h. 9.

Abdullah A. Al-Naim, "Human Right In The Arab World: A Regional Perspective", Human Rights Querterly, vol. 23 no. 3. http://eprints.walisongo.ac.id/9152/1/122211003.pdf\&ved (Diakses 26 Maret).

Abu Ishaq Ibrahim Al-Syatibi, Al-Muwafaqat Fi Usul Al-Syari'ah, Juz 1 (Beirut: Dar Al-Kutub Al-Ilmiyyah, t.th), h. 54.

Adian Husaini, LGBT di Indonesia: Perkembangan dan Solusinya (Jakarta: Insist, t.th), h. 2.

Agus Dedi Putrawan, Membumikan Deklarasi Kairo Di Indonesia, h. 183. www.Google. Com (Diakses 01 April 2019).

Ali Syari'at, Rasulullah Hijrah Hingga Wafat Tinjauan Kritis Sejarah Nabi Periode Madinah (Cet. II; Bandung: Pustaka Hiayah, 1995), h. 30-39. 
Anindita Ayu Pradipta Yaudah dan Irak Sulhin, Representasi Transgender dan Transeksual dalam Pemberitaan di Media Massa. http:/ /journal.ui.ac/index.php (Diakses 14 Oktober 2018).

Ann Elizabeth Mayer, Islam and Human Raight: Traditian And Politics, Edisi Ketiga (Colorado: Westview Press, 1999), h. 203-208.

Ann Elizabeth Mayer, Islam and Human Right: Tradition and Politics, h. 22.

Arzoo Osaloo, “The Measure Of Mercy: Islamic Justice, Sovereign Power and Human Rights In Iran", Cultur Anthropology, vol. 21 no. 4. http:www.neliti.com/journals/sinergi-jurnal-teknik-mercbuana\%3D4\&ved (Diakses 26 Maret 2019).

Bambang Heri Supriyanto, Penegakan Hukum Mengenai Hak Asasi Manusia (Ham) Menurut Hukum Positif Di Indonesia, h.152. www.Google.Com (Diakses 01 April 2019).

Chorul Nur Akrom, "Transgender dalam Perspektif Hukum Positif dan Hukum Islam". Skripsi (Palembang: Fakultas Syariah dan Hukum UIN Raden Fatah, 2017).

Elfi Munawarah, Pendidikan Gender dan Hak Asasi Manusia (Yogyakarta: Teras, 2009), h.18.

Fitri Meliya Sari, "Konstruksi Media Terhadap Transgender", Jurnal profesional UNIVED, vol. 3 no. 1 (Juni 2016), h. 27. https://jurnal.unived.acid/index.php/prof/article/download/290/277/ \& ved (Diakses 12 Februari 2019).

Fitri Meliya Sari, "Konstruksi Media Terhadap Transgender", Jurnal profesional UNIVED, vol. 3 no. 1 (Juni 2016), h. 27. https://jurnal.unived.acid/index.php/prof/article/download/290/277/ \&ved (Diakses 17 Februari 2019).

Gibtiah, Figh Kontemporer (Palembang: Karya Sukses Mandiri, 2015), h. 272.

Hamid Fahmi Zarkasyi, Islam Ham dan Keberagaman Agama (Jakarta: INSISTS, 2011), h. 15.

Hartanto, Hegemoni Dalam Emansipatory: Studi Kasus Advokasi Legalisasi Lesbian, Gay, Biseksual, dan Transgender (LGBT) Di Indonesia. http:/ / ejournal.undip.ac.id (Diakses 20 Februari 2019).

Hartanto, Hegemoni Dalam Emansipatory: Studi Kasus Advokasi Legalisasi Lesbian, Gay, Biseksual, dan Transgender (LGBT) Di Indonesia. http:/ / ejournal.undip.ac.id (Diakses 04 November 2018).

Hendri Shalauddin, "Menyongsong Kebangkitan Kaum Nabi Luth Di Indonesia", http://Thisisgender.Com (Diakses 20 Februari 2019).

Icha's World, Ham: Universal Declaration of Human Right). http:/ Www.Google.Com/ Amp/S/Ichaimucu.Wordpress.Com/2011/03/02/Ham-UniversalDeclaration-Of-Human-Right-1948/ Amp/ (Diakses 27 Maret 2019).

Ihsan Ali Fauzi, Hak Asasi Manusia (Jakarta: PT. Ikhtiar Baru Van Hoeve, 2002), h. 161.

Internasional Law Making, "Deklarasi Universal Hak-Hak Asasi Manusia”, Jurnal Hukum Intenasional, vol. 4 no. 1 (Oktober 2006), h. 133-135. 
http://ijil.ui.ac.id/index.php/home/article/ download/468/pdf_354\&ved (Diakses 24 Maret 2018).

Internasional Law Making, "Deklarasi Universal Hak-Hak Asasi Manusia", Jurnal Hukum Intenasional, vol. 4 no. 1 (Oktober 2006), h. 135. http://ijil.ui.ac.id/index.php/home/article/download /468/pdf_354\&ved (Diakses 24 Maret 2018).

Izzuddin Washil dan Ahmad Khoirul Fata, "Ham Islam dan Duham PBB: Sebuah Ikhtiar Mencari Titik Temu", MIQOT, Vol. XLI no. 2 (JuliDesember 2017), h. 437. http://media. nelti.com/ media/publications/255994-ham-islam-dan-duham-pbb-sebuah-ikhtiarmencari-titik-temuc27746c.pdf \&ved (Diakses 29 Maret 2019).

Koeswinardo, Hidup Sebagai Waria (Yogyakarta: PT. Lkis Pelangi Aksara, 2004), h. 54 .

Krista Marsha Esterlita, Dilema Pengungkapan Identitas Wanita Transeksual: Kajian Fenomonologi Wanita Transeksual Di Surabaya.

Martinus Sardi, Mengenal Hak Asasi Manusia dalam Islam Berdasarkan Deklarasi Kairo, $\mathrm{h}$. 390. http://repository.imy.ac.id/bitstream/handke/123456789/3914Martinus $\% 2529$ Sardi\%_Mengen

al\%2520HAM\%dalam\%2520Islam\%2520\%Berdasarkan\%Deklarasi $\% 2510 \%$ Kairo.pdf\%3Fsequence \%3D1\&ved (Diakses 29 Maret 2019).

Meilanny Budiarti Santoso, "LGBT Dalam Perspektif Hak Asasi Manusia", Sosial Work Journal, vol. 6 no. 2 (2016), h. 221. http://jurnal.unpac.id.ac.id/share/article/download/ 13206/6036\&ved (Diakses 14 Oktober 2018).

Meilanny Budiarti Santoso, "LGBT Dalam Perspektif Hak Asasi Manusia", Sosial Work Journal, vol. 6 no. 2 (2016), h. 227. http://jurnal.unpac.id.ac.id/sh are/ article/download/13206/6036\& ved (Diakses 29 Maret 2019).

Meilanny Budiarti Santoso, "LGBT Dalam Perspektif Hak Asasi Manusia", Sosial Work Journal, vol. 6 no. 2 (2016), h. 222. http://jurnal.unpac.id.ac.id/share/ article/download/13206/6036\& ved (Diakses 26 Oktober 2018).

Muhammad Luthfan Setiaji dan Aminullah, "Kajian Hak Asasi Manusia dalam Negara The Rule Of Law: Antara Hukum Progresif dan Hukum Positif", h.70. www.Google.Com (Diakses 29 Maret 2019).

Muhammad Rizki Akbar Pratama, dkk., "Lesbian, Gay, Biseksual dan Transgender: Tinjauan Teori Psikoseksual, Psikologi Islam dan Biopsikologi", Jurnal Psikologi Islami, vol. 4 no. 2 (Juni 2018), h. 28. http://jurnal.radenfatah.ac.id/index.php/psikis/article/download/2157 /1569/\&ved (Diakses 14 Oktober 2018).

Muhammad Rizki Akbar Pratama, dkk., "Lesbian, Gay, Biseksual Dan Transgender: Tinjauan Teori Psikoseksual, Psikologi Islam dan Biopsikologi", Jurnal Psikologi Islami, vol. 4 no. 2 (Juni 2018), h. 29. http://jurnal.radenfatah.ac.id/index.php/psikis/article/download/2157 
/1569/\&ved (14 Oktober 2018).

Naylin Najihah, Deklarasi Oki Di Kairo, www.Academia.Edu/10452815/Deklarasi_

Kairo_Translated_By_Naylin_Najihah_\&Ved (Diakses 26 Maret 2019).

Pius A. Partanto dan M Dahlan Al-Barry, Kamus Ilmiah Populer (Surabaya: Arkola, t.th), h. 757.

Robi Yansyah dan Rahayu,"Globalisasi Lesbian, Gay, Biseksual dan Tansgender (Lgbt); Perspektif Ham dan Agama", Journal Law Reform, vol. 14 no. 1 (2018), h.137.

https:/ /Ejournal.Undip.Ac.Id/Index.Pp/Lawreform/Article/Wiew/2024 2, h.135 (Diakses 24 April 2019).

Roby Yansyah dan Rahayu, "Globalisasi Lesbian, Gay, Biseksual dan Tansgender (Lgbt): Perspektif Ham dan Agama", Journal Law Reform, vol. 14 no. 1 (2018), h.137. https:/ /Ejournal.Undip.Ac.Id/Index.Pp/Lawreform/Article/Wiew/2024 2 (Diakses 25 April 2019).

Roby Yansyah dan Rahayu,"Globalisasi Lesbian, Gay, Biseksual dan Tansgender (Lgbt): Perspektif Ham dan Agama", Journal Law Reform, vol. 14 no. 1 (2018), h.137. https:/ /Ejournal.Undip.Ac.Id/Index.Pp/Lawreform/Article/Wiew/2024 2 (Diakses 20 April 2019).

Suhaimi Razak, "Lgbt Dalam Perspektif Agama”, Madura al-Ibrah, vol. 1 no. 1 (Juni 2016), h. 54. Download.Garuda.Risetdikti.Go.Id (Diakses 14 oktober 2018).

Sunaryo, "Studi Komparatif Antara the Declaration of Human Right 1948 dan the Cairo Declaration of Human Right In Islam 1990", h. 390. http://Jurnal.Fh.Unila.Ac.Id/Index.Php/Fiat/ Article/View/61/0\&Ved (Diakses 24 Maret 2018).

Sunaryo, "Studi Komparatif Antara the Declaration Of Human Right 1948 dan the Cairo Declaration Of Human Right 1990", h. 390. http://Jurnal.Fh.Unila.Ac.Id/Index.Php/Fiat/Article/View/ 61/0\&Ved (Diakses 24 Maret 2018).

Sunaryo, "Studi Komparatif Antara The Universal Declaration Of Human Right 1948 Dan The Cairo Declaration Of Human Right In Islam 1990", Fiat Justitia Ilmu Hukum, vol. 5 no. 2 (2012), h.349. Jurnal.Fh.Unila.Ac.Id/Index.Php/Fiat/Article/View/61 (Diakses 24 April 2019).

Sunaryo, "Studi Komparatif Antara The Universal Declaration Of Human Right 1948 Dan The Cairo Declaration Of Human Right In Islam 1990", Fiat Justitia Ilmu Hukum, vol. 5 no. 2 (2012), h.349. Jurnal.Fh.Unila.Ac.Id/Index.Php/Fiat/Article/View/61 (Diakses 24 April 2019).

Sunaryo, "Studi Komparatif Antara The Universal Declaration Of Human Right 1948 dan The Cairo Declaration Of Human Right In Islam 1990", Fiat Justitia Ilmu Hukum, vol. 5 no. 2 (2012), h. 403. 
Jurnal.Fh.Unila.Ac.Id/Index.Php/Fiat/Article/View/61 (Diakses 24 April 2019).

Taufik Abdullah, Ensiklopedia Tematis Dunia Islam, Penerbit Anonim. 